\title{
Atrial septal defect closure via mini-thoracotomy in pediatric patients: Postoperative analgesic effect of intercostal nerve block
}

\author{
Pediatrik hastalarda mini-torakotomi ile atriyal septal defekt kapatılmasl: \\ interkostal sinir blokunun ameliyat sonrası analjezik etkisi
}

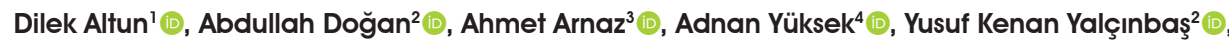 \\ Rıza Türköz² ${ }^{\mathbb{D}}$, Sinan Aşar ${ }^{5}$ (i), Tayyar Sarıoğlúb
}

\author{
Institution where the research was done: \\ Acıbadem Bakırköy Hospital, Istanbul, Turkey \\ Author Affiliations: \\ 'Department of Anesthesiology and Reanimation, Acıbadem Mehmet Ali Aydınlar University, Vocational School of Health Sciences, Istanbul, Turkey \\ ${ }^{2}$ Department of Cardiovascular Surgery, Acıbadem Bakırköy Hospital, Istanbul, Turkey \\ ${ }^{3}$ Department of Cardiovascular Surgery, Acıbadem Mehmet Ali Aydınlar University Medical Faculty, Istanbul, Turkey \\ ${ }^{4}$ Department of Anesthesiology and Reanimation, Acıbadem Bakırköy Hospital, Istanbul, Turkey \\ ${ }^{5}$ Department of Anesthesiology and Reanimation, Bakırköy Dr. Sadi Konuk Training and Research Hospital, Istanbul, Turkey \\ ${ }^{6}$ Department of Pediatric Cardiovascular Surgery, Acıbadem Mehmet Ali Aydinlar University Medical Faculty, Istanbul, Turkey
}

\section{ABSTRACT}

Background: In this study, we evaluated the efficacy of intercostal nerve block for postoperative pain management in pediatric patients undergoing atrial septal defect closure through a right lateral mini-thoracotomy.

Methods: Between January 2016 and January 2019, a total of 63 pediatric patients (37 males, 26 females; mean age $34.8 \pm 26.8$ months; range, 2 to 96 months) who underwent corrective congenital heart surgery for atrial septal defect closure through a right lateral mini-thoracotomy were retrospectively reviewed. The patients were divided into two groups as those (Group 1, $n=33$ ) receiving intercostal nerve block and general anesthesia and those (Group 2, n=30) receiving general anesthesia alone. Intravenous morphine at a dose of $0.03 \mathrm{mg} / \mathrm{kg}$ was applied as rescue analgesia to the patients with a Ramsay Sedation Scale score of $>4$ and Children's Hospital of Eastern Ontario Pain Scale score of $>7$. The total analgesic requirement, adverse effects, duration of mechanical ventilation and length of stay in the intensive care unit were recorded.

Results: The mean duration of mechanical ventilation and intensive care unit stay was shorter in Group 1 compared to Group 2 (3.6 \pm 1.3 vs. $9.4 \pm 2.1 \mathrm{~h}$; $23 \pm 2.6$ vs. $30 \pm 7.2 \mathrm{~h}$, respectively) $(\mathrm{p}<0.0001)$. The need for postoperative rescue analgesia was statistically significantly lower in Group 1 compared to Group $2(0.3 \pm 0.5 \mathrm{mg}$ vs. $1.1 \pm 0.9 \mathrm{mg}$, respectively) ( $\mathrm{p}=0.003)$. The mean total morphine consumption was also lower in Group 1 compared to Group 2 ( $4.0 \pm 2.2 \mathrm{mg}$ vs. $9.0 \pm 3.4 \mathrm{mg}$, respectively) $(\mathrm{p}<0.0001)$.

Conclusion: Intercostal nerve block before thoracotomy closure in pediatric patients undergoing atrial septal defect repair under mini-thoracotomy provides early extubation, shorter mechanical ventilation duration and intensive care unit stay, and reduced analgesic requirements.

Keywords: Atrial septal defect, intercostal nerve block, mini-thoracotomy, pediatric cardiac surgery, postoperative analgesia.
$\ddot{O} Z$

Amaç: Bu çalışmada, sağ lateral mini-torakotomi ile atriyal septal defekt kapatılması yapılan pediatrik hastalarda interkostal sinir blokunun ameliyat sonrası ağrı yönetimindeki etkinliği değerlendirildi.

Çalışma planı: Ocak 2016 - Ocak 2019 tarihleri arasında să̆ lateral minitorakotomi ile atriyal septal defekt kapatılması için düzeltici doğuştan kalp cerrahisi yapılan toplam 63 pediatrik hasta (37 erkek, 26 kız; ort. yaş $34.8 \pm 26.8$ ay; dağılım, 2-96 ay) retrospektif olarak incelendi. Hastalar interkostal sinir bloku ve genel anestezi verilenler (Grup 1, $n=33$ ) ve yalnızca genel anestezi verilenler (Grup 2, n=30) olmak üzere iki gruba ayrıldı. Ramsay Sedasyon Ölçeği skoru $>4$ ve Doğu Ontario Çocuk Hastanesi A ̆grı Ölçeği skoru $>7$ olan hastalara kurtarma analjezisi olarak $0.03 \mathrm{mg} / \mathrm{kg}$ dozunda intravenöz morfin uygulandı. Toplam analjezik gereksinimi, yan etkiler, mekanik ventilasyon süresi ve yoğun bakım ünitesinde kalışs süresi kaydedildi.

Bulgular: Ortalama mekanik ventilasyon ve yoğun bakım ünitesinde kalış süresi Grup 1'de Grup 2'ye kıyasla daha kısa idi (sırasıyla, 3.6 \pm 1.3 'e kıyasla $9.4 \pm 2.1$ saat; $23 \pm 2.6$ 'ya kiyasla $30 \pm 7.2$ saat $)(\mathrm{p}<0.0001)$. Ameliyat sonras kurtarma analjezi ihtiyacı Grup 1'de Grup 2'ye kıyasla istatistiksel olarak anlamlı düzeyde daha düşüktü (sırasıyla, $0.3 \pm 0.5 \mathrm{mg}$ 'ye kiyasla $1.1 \pm 0.9 \mathrm{mg}$ ) $(\mathrm{p}=0.003)$. Ortalama toplam morfin tüketimi de Grup 1'de Grup 2'ye kiyasla daha düşüktü (sırasıyla, $4.0 \pm 2.2 \mathrm{mg}$ 'ye kıyasla $9.0 \pm 3.4 \mathrm{mg}$ ) $(\mathrm{p}<0.0001)$.

Sonuç: Mini-torakotomi ile atriyal septal defekt onarımı yapılan pediatrik hastalarda torakotomi kapatılmadan önce interkostal sinir bloku, erken ekstübasyon, daha kısa mekanik ventilasyon ve yoğun bakım ünitesinde kalış süresi ve daha az analjezik gereksinimi sağlar.

Anahtar sözcükler: Atriyal septal defekt, interkostal sinir bloku, mini-torakotomi, pediatrik kalp cerrahisi, ameliyat sonrası analjezi.

Received: December 13, 2019 Accepted: January 22, 2020 Published online: April 22, 2020

Correspondence: Dilek Altun, MD. Acıbadem Bakırköy Hastanesi, Halit Ziya Uşaklıgil Cad, No: 1, 34140 Bakırköy, İstanbul, Türkiye. Tel: +90 212 - 4145117 e-mail: drdilekaltun@hotmail.com effect of intercostal nerve block. Turk Gogus Kalp Dama 2020;28(2):257-263 
Pain management after congenital cardiac surgery is challenging. In particular, after the operations performed under thoracotomy, the degree of pain can be greater than the operations performed under median sternotomy. Thoracotomy is one of the most painful techniques. ${ }^{[1-3]}$

Postoperative pain management is important for these patients in terms of effective pulmonary functions and improved compliance with coughing and deep breathing, thereby decreasing the risk of pulmonary atelectasis and ventilation-perfusion abnormalities. ${ }^{[1,2]}$

Although opioids are still the most common analgesic agents used after congenital heart surgery due to their excellent pharmacological properties for sedation and analgesia, their prolonged use is associated with several side effects, including respiratory depression and prolonged mechanical ventilation (MV). Furthermore, nausea and vomiting are the frequent adverse effects related to opioids. ${ }^{[1-5]}$

Regional anesthesia including intercostal nerve block (ICNB) has major advantages of providing effective analgesia without the central respiratory depression and gastrointestinal side effects related to the high dose of opioids. ${ }^{[1-4]}$ The ICNB is a simple technique which can be performed easily by clinicians and provides effective analgesia with improved pulmonary mechanics, reduced central nervous system (CNS) depression. ${ }^{[3,4]}$ In the present study, we aimed to evaluate the effects of ICNB with a long-acting local anesthetic combined with general anesthesia on postoperative pain, extubation time, and length of stay in the cardiovascular intensive care unit (CICU) in patients undergoing atrial septal defect (ASD) closure with right thoracotomy.

\section{PATIENTS AND METHODS}

This retrospective study was conducted at Bakirkoy Private Acibadem Hospital between January 2016 and January 2019. A list of all pediatric patients admitted to the pediatric cardiac intensive care unit was searched. A total of 63 patients ( 37 males, 26 females; mean age $34.8 \pm 26.8$ months; range, 2 to 96 months) who underwent corrective congenital heart surgery for ASD closure through a right lateral mini-thoracotomy were included. The patients were divided into two groups. Group $1(n=33)$ included the patients with ICNB and general anesthesia, while Group $2(n=30)$ included the patients with general anesthesia alone. A written informed consent was obtained from each parent. The study protocol was approved by Acıbadem University, School of Medicine, Ethics Committee Ethics Committee (2019-14/44). The study was conducted in accordance with the principles of the Declaration of Helsinki.

We reviewed the medical charts and nursing documentation of all patients. Clinical data including hemodynamic parameters heart rate (HR), systolic arterial pressure (SAP), diastolic arterial pressure (DAP), mean arterial pressure (MAP), oxygen saturation measured via pulse oximetry, duration of MV and length of stay in CICU, requirements for additional sedative/analgesic drugs, and adverse effects (arrhythmia, hypotension, bradycardia episodes, hypertension, pruritus, vomiting, atelectasis, constipation, bowel immobility) were recorded.

The Ramsay Sedation Scale (RSS) was recorded for $24 \mathrm{~h}$ following surgery for the assessment of sedation and the criteria were as follows: (i) agitated and uncomfortable; (ii) cooperative and oriented; (iii) obeys simple directions; (iv) sleepy with strong reply to stimulation; $(v)$ sleepy with slow reply to stimulation; and (vi) asleep and does not reply to stimulation. ${ }^{[6]}$ The Children's Hospital of Eastern Ontario Pain Scale (CHEOPS) was used for the assessment of pain management (Table 1). ${ }^{[7]}$ If sedation/analgesia was considered inadequate by the bedside nurse and by the physician on duty, rescue analgesia of morphine of $0.03 \mathrm{mg} / \mathrm{kg}$ was given in all patients with a RSS score of $>4$ and CHEOPS score of $>7$ patients which are the inadequate sedation levels.

Table 1. The Children's Hospital Eastern Ontario Pain Scale (CHEOPS)

\begin{tabular}{lccc}
\hline Score & 0 & 1 & 2 \\
\hline Cry & No cry & Crying/morning & Scream \\
Facial expression & Smiling/positive & Neutral & Grimace \\
Verbal expression & Positive statement & Negative statement & Suffering from pain, another complaint \\
Torso & Neutral & Variable, taut, upright & Stretched \\
Legs & Neutral & Kicking & Stretched, continuous move \\
\hline
\end{tabular}




\section{Operative technique}

All operations were conducted by a single surgeon team using the same technique with a right lateral minithoracotomy through the fourth or fifth intercostal space. Anesthesia was induced in all patients with thiopental $(4-6 \mathrm{mg} / \mathrm{kg})$, fentanyl $(8-10 \mu \mathrm{g} / \mathrm{kg})$, and vecuronium $(0.08 \mathrm{mg} / \mathrm{kg})$ and maintained with fentanyl infusion $(8 \mu \mathrm{g} / \mathrm{kg} / \mathrm{h}), 0.5$ to $0.7 \%$ isoflurane in oxygen-air mixture, and intravenous injections of vecuronium $(0.02 \mathrm{mg} / \mathrm{kg}$ every $30 \mathrm{~min})$. Intercostal nerve block was applied to the intercostal space of the performed thoracotomy with one upper and one lower intercostal space with a single dose of $0.5 \mathrm{mg} / \mathrm{kg} 0.5 \%$ bupivacaine (AstraZeneca AB, Södertalje, Sweden) with $0.9 \%$ saline on each intercostal space (T3-T7) under the parietal pleura, $2-\mathrm{cm}$ lateral to the sympathetic chain with $25-\mathrm{G}$ needle under direct vision after bleeding control and before thoracotomy closure. The bupivacaine and saline preparations were prepared by diluting $0.5 \%$ bupivacaine with normal saline in the ratio of $1: 1$ in the operating room by a cardiac anesthesiologist as a routine protocol of our institution.

After the operation, morphine infusion at a dose of 0.01 to $0.04 \mathrm{mg} / \mathrm{kg} / \mathrm{h}$ infusion was administered to all patients in both groups and continued up to $24 \mathrm{~h}$ in the CICU as a routine protocol of our institution. The dose was titrated on an hourly basis with evaluating patients according to the RSS and CHEOPS scores to achieve RSS score of 2 to 4 and CHEOPS score of 0 to $7 \mathrm{by}$. After $24 \mathrm{~h}$, pain management of all patients was done with non-steroidal anti-inflammatory drugs (NSAIDs) (ibuprofen was given at a dose of $10 \mathrm{mg} / \mathrm{kg}$ for all patients after $24 \mathrm{~h}$ of CICU stay three times a day). After the CICU stay, all patients were checked at specific time intervals by a single investigator until $48 \mathrm{~h}$.
If sedation/analgesia was considered inadequate, morphine of $0.03 \mathrm{mg} / \mathrm{kg}$ was given as rescue analgesia to the patients with a RSS score of $>4$ and CHEOPS score of $>7$.

All patients were continuously monitored with electrocardiogram and pulse oximetry and had an arterial and central venous catheter line during the CICU stay. Vital signs and clinical parameters were checked on an hourly basis, as per nursing protocol, and medications were recorded at least four times a day, or when the dose was modified.

Children who met extubation criteria including effective spontaneous breathing, absence of residual muscle paralysis, response to verbal orders, stable hemodynamic parameters, urine output $>0.5 \mathrm{~mL} / \mathrm{kg} / \mathrm{h}$ without active bleeding, and oropharyngeal temperature above $36^{\circ} \mathrm{C}$ were extubated.

\section{Statistical analysis}

Based on the power analysis, the number of samples determined for power: $0.80, \beta$ : 0.20 and $\alpha$ : 0.05 was calculated as minimum 12 patients for each group, when the difference (D) 12 was considered for the morphine consumption.

The GraphPad Prism version 5.01 software (GraphPad Software Inc., La Jolla, CA, USA) was used for all data analysis. Descriptive statistics were expressed in mean \pm standard deviation (SD), median (min-max) or number and frequency with confidence interval (CI) values. Homogeneity of the variables was determined using the ShapiroWilk normality test. The Student's t-test was used for independent and homogeneous binary variables and the Mann-Whitney U test was used for nonhomogeneous binary variables. A $p$ value of $<0.05$ was considered statistically significant.

Table 2. Baseline characteristics of patient groups

\begin{tabular}{|c|c|c|c|c|c|c|c|}
\hline & \multicolumn{3}{|c|}{ Group 1 (ICNB) } & \multicolumn{3}{|c|}{ Group 2 (IV) } & \multirow[b]{2}{*}{$p$} \\
\hline & $\mathrm{n}$ & $\%$ & Mean \pm SD & $\mathrm{n}$ & $\%$ & Mean \pm SD & \\
\hline Age (month) $\dagger$ & & & $41.6 \pm 30.5$ & & & $27.9 \pm 20.8$ & 0.12 \\
\hline Weight $(\mathrm{kg}) \dagger$ & & & $15.2 \pm 7.1$ & & & $10.4 \pm 4.7$ & $0.03 *$ \\
\hline Cardiopulmonary bypass time (min) & & & $57.0 \pm 10.6$ & & & $60.8 \pm 9.3$ & 0.149 \\
\hline Aortic cross-clamp time (min) & & & $26.9 \pm 8.8$ & & & $29.8 \pm 10$ & 0.229 \\
\hline \multicolumn{8}{|l|}{ Gender } \\
\hline Female & 13 & 39.3 & & 13 & 43.3 & & 1 \\
\hline Male & 20 & 60.6 & & 17 & 56.6 & & 1 \\
\hline
\end{tabular}

SD: Standard deviation; $\dagger$ Mann-Whitney U test; $* \mathrm{p}<0.05$ 


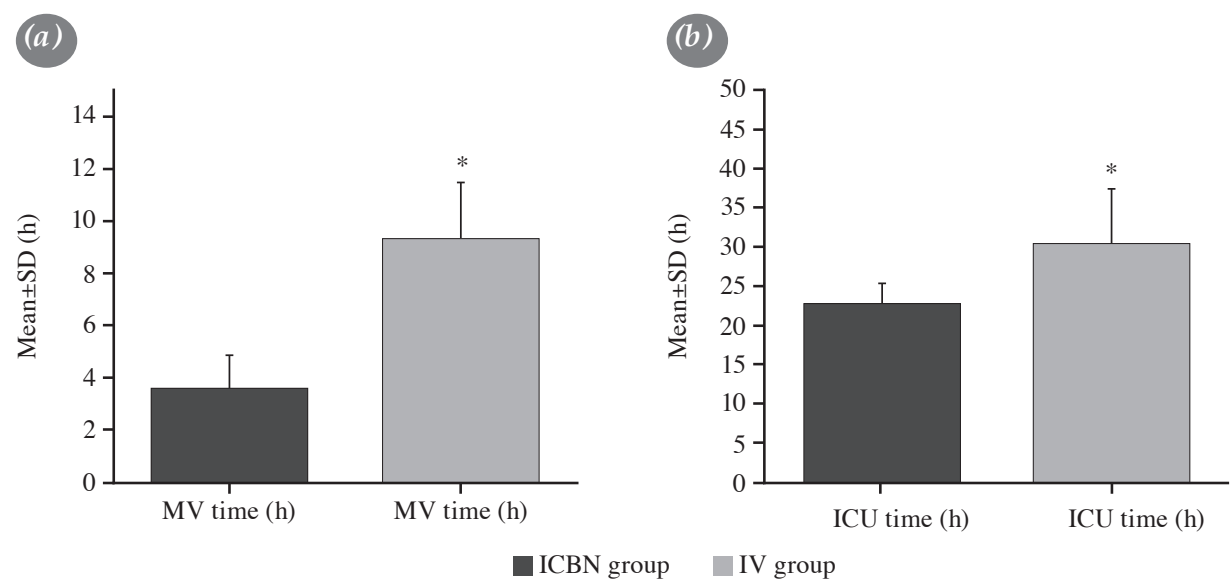

Figure 1. Mechanical ventilation and intensive care unit duration.

SD: Standard deviation; MV: Mechanical ventilation; ICU: Intensive care unit; ICNB: Intercostal nerve block; IV: Intravenous; Mann Whitney U test; * $\mathrm{p}<0.001$.

\section{RESULTS}

There was no significant difference in the baseline demographics between the groups (Table 2). The mean SAP, DAP, and MAP values were within the normal ranges, and there were no differences in the hemodynamic parameters between the groups ( $p>0.05$ ). However, the mean MV duration of Group 1 was significantly shorter than Group 2 $(3.6 \pm 1.3 \mathrm{~h}$ in Group 1 and $9.4 \pm 2.1 \mathrm{~h}$ in Group 2) $(p<0.0001)$ (Figure 1a). The mean length of stay in the intensive care unit was also shorter in Group 1 than Group 2 (23 $\pm 2.6 \mathrm{~h}$ in Group 1 and $30 \pm 7.2 \mathrm{~h}$ in Group 2) $(p<0.0001)$ (Figure 1b). The need for postoperative rescue analgesia (morphine) was significantly lower for patients receiving ICNB than patients receiving only general anesthesia $(0.3 \pm 0.4 \mathrm{mg}$ in Group 1 and $1.1 \pm 0.9 \mathrm{mg}$ in Group 2) $(\mathrm{p}=0.003)$ (Figure 2a). The mean postoperative total morphine consumption was also significantly lower in patients receiving ICNB than patients receiving only general anesthesia (4.0 $\pm 2.2 \mathrm{mg}$ in Group 1 and $9.0 \pm 3.3 \mathrm{mg}$ in Group 2, respectively) $(\mathrm{p}<0.0001)$ (Figure $2 \mathrm{~b})$. The HR was statistically significantly lower in all time points in Group 1, compared to Group $2(\mathrm{p}<0.05)$ (Figure 3). The CHEOPS and RSS scores of Group 2 were higher than Group 1 in all time points, expect for the early and late postoperative period (before transfer to the ward) $(\mathrm{p}<0.05 ; \mathrm{p}<: 0.01 ;$ and $\mathrm{p}>0.05$, respectively) (Figures 4, 5, Table 1).

There was no significant difference in terms of adverse reactions including arrhythmia, hypotension, hypertension, pruritus, vomiting, atelectasis, and constipation between the groups $(p>0.05)$ There was no significant difference between the groups in terms of surgical procedural variables such as aortic crossclamp time and cardiopulmonary bypass time $(\mathrm{p}>0.05)$ (Table 2).
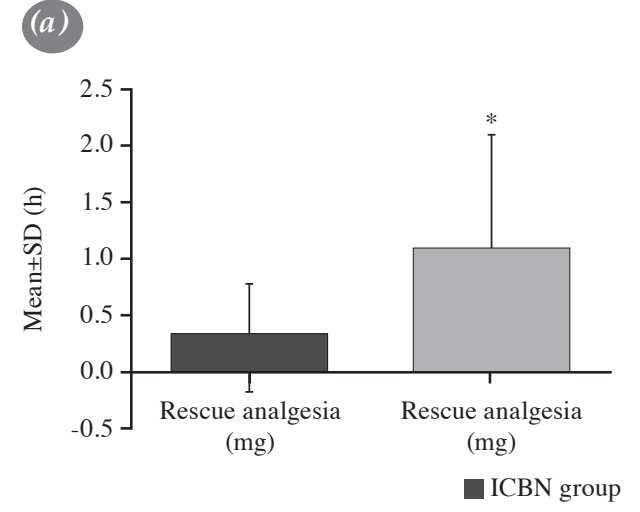
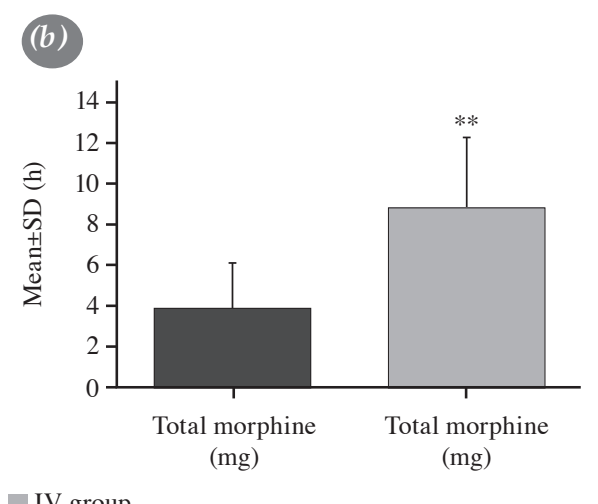

Figure 2. Rescue analgesia and total morphine consumption.

SD: Standard deviation; ICNB: Intercostal nerve block; * $\mathrm{p}<0.05 ; * * \mathrm{p}<0.01$; Mann Whitney U test. 


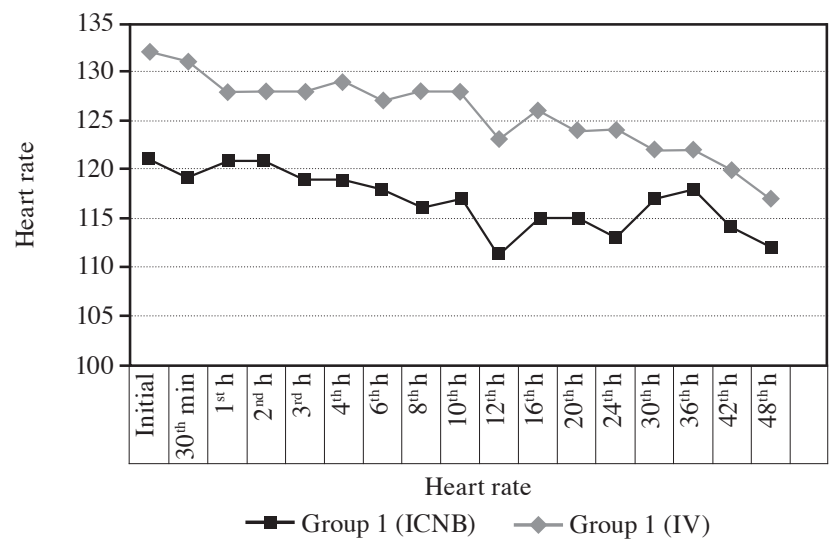

Figure 3. Heart rates of patient groups. ICNB: Intercostal nerve block; IV: Intravenous.

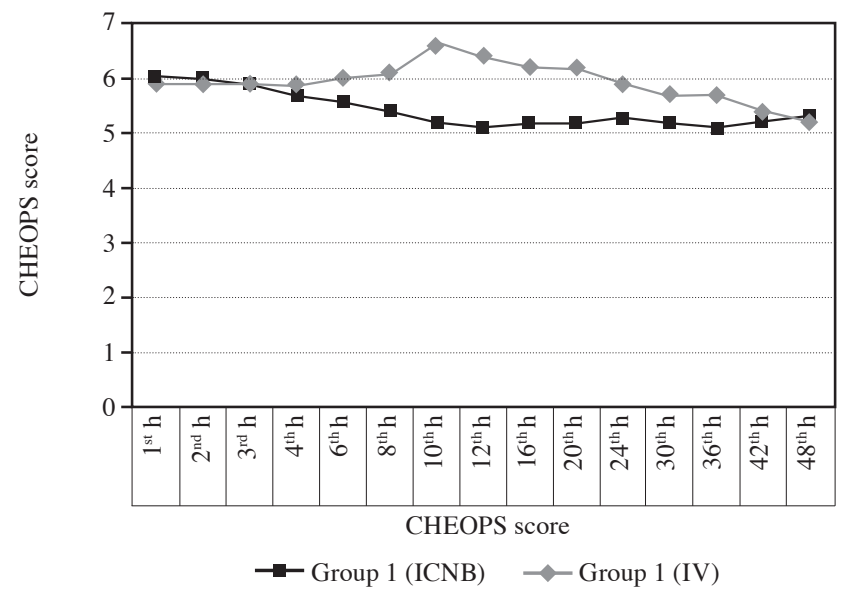

Figure 4. Children's Hospital of Eastern Ontario Pain Scale scores of patient groups.

CHEOPS: Children's Hospital of Eastern Ontario Pain Scale; ICNB: Intercostal nerve block; IV: Intravenous.

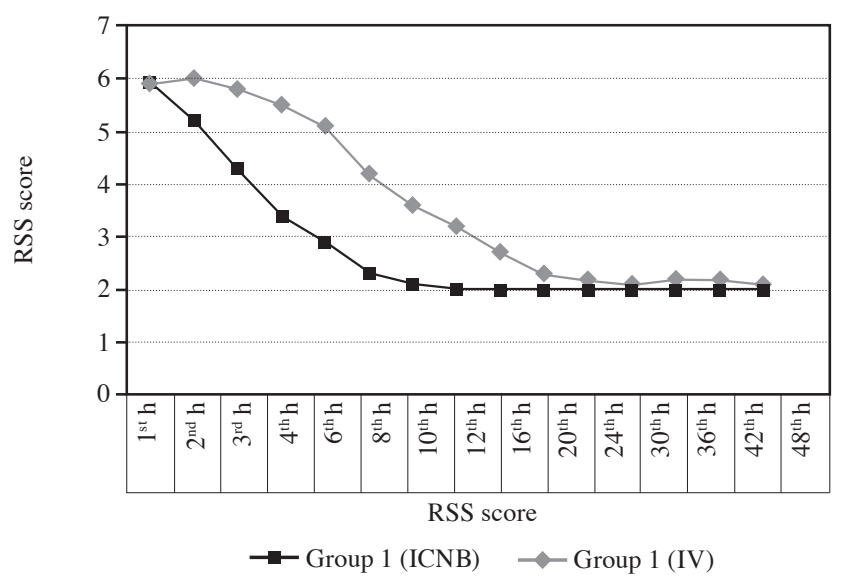

Figure 5. Ramsay Sedation Scale scores of patient groups. RSS: Ramsay Sedation Scale; ICNB: Intercostal nerve block; IV: Intravenous.

\section{DISCUSSION}

In this retrospective study, we investigated the efficacy of parasternal ICNB in terms of opioid consumption, MV and CICU duration after ASD closure operations performed with mini-thoracotomy in pediatric patients. According to our study results, parasternal ICNB applied perioperatively significantly decreased opioid consumption and MV and CICU duration with effective pain control during the postoperative $48 \mathrm{~h}$ in patients who underwent ASD closure through mini-thoracotomy.

Effective postoperative pain management for early and safe extubation is one of the most important issues which affect the complication rates and costs in congenital heart surgery. An ICNB under direct vision with a long-acting local anesthetic agent is easy to perform and has low risks of complications which can provide satisfactory pain management after procedures performed via thoracotomy.

Patients experience serious pain in the early postoperative period after thoracotomy, compared to sternotomy. Although conventional analgesic agents, particularly morphine, are still the most preferred analgesic agents for postoperative analgesia, high-dose and long-term usage have many side effects such as longer MV and CICU duration, withdrawal syndrome, or abnormal intestinal motility. To avoid these side effects, regional techniques such as thoracic epidural analgesia, and intrapleural or ICNB have been used as an alternative method for pain management in the early postoperative period. Among these modalities, the ICNB has been shown to provide satisfactory pain relief with decreased opioid consumption and fewer potential complications. ${ }^{[3-5,8-10]}$

Several studies have shown that the ICNB improves postoperative pulmonary functions, while decreasing opioid consumption, and reduces associated complications by providing improved postoperative pain control. ${ }^{[4,10-16]}$ Similar to our study, Barr et al..$^{[4]}$ found reduced pain scores and total opioid consumption in the patients where they performed operations with parasternal ICNB for pain management after adult cardiac surgery. Lukosiene et al. ${ }^{[17]}$ also conducted a study in pediatric patients undergoing minimally invasive thoracic surgery where they evaluated the efficacy of ICNB on acute pain management after the Nuss procedure. Similar to our findings, they found improved pain scores with less morphine consumption in the ICNB group after the operation. We also found improved pain and sedation scores in Group 1 (ICNB group) compared to Group 2 (intravenous group) 
with less morphine consumption. Luo et al. ${ }^{[14]}$ also demonstrated that the ICNB was more effective than patient-controlled intravenous analgesia in pediatric patients undergoing the Nuss procedure during the acute postoperative period. According to our study results, ICNB provided better analgesia for pain control after ASD repair performed with mini-thoracotomy. The ICNB also decreased the MV duration, thus CICU duration, by reducing opioid consumption and improving pulmonary functions. After congenital heart surgery, particularly after thoracotomy procedures, inadequate analgesia may lead to adverse circulatory and respiratory events. ${ }^{[1-5]}$ Systemic NSAIDs alone may not be effective as opioids and may cause gastrointestinal and renal complications. ${ }^{[18]}$

Furthermore, the success rates for conventional regional approaches including epidural anesthesia, percutaneous ICNB, serratus anterior plane block, pectoral nerve blocks, and paravertebral blocks are highly dependent on the operator skills which are associated with increased serious complications. ${ }^{[3-5,8]}$ The ICNB performed before the thoracotomy closure by the surgeon under direct vision increases the success rate, while decreasing complications related to the ICNB. Besides being easy to perform, block under direct visualization, and improved analgesic effects, there are many other advantages including improved pulmonary functions, reduced CNS depression, and avoidance of urinary retention. ${ }^{[16-18]}$ Chaudhary et al. ${ }^{[18]}$ investigated the efficacy and safety of ICNB and demonstrated better outcomes and improved pain management with parasternal ICNB, which is a technically simple and safe way of analgesic management in children undergoing cardiac surgery.

The retrospective and non-randomized design of the study with a relatively low sample size are the main limitations of the study. In addition, this study has a relatively short follow-up period. We recommend further prospective, large-scale, long-term studies to confirm these findings.

In conclusion, intercostal nerve block performed at the end of the operation before thoracotomy closure may reduce opioid consumption with better analgesic effects, promote early extubation, shorten the duration of mechanical ventilation and cardiovascular intensive care unit stay with improved early postoperative recovery.

\section{Declaration of conflicting interests}

The authors declared no conflicts of interest with respect to the authorship and/or publication of this article.

\section{Funding}

The authors received no financial support for the research and/or authorship of this article.

\section{REFERENCES}

1. Zubrzycki M, Liebold A, Skrabal C, Reinelt H, Ziegler M, Perdas E, et al. Assessment and pathophysiology of pain in cardiac surgery. J Pain Res 2018;11:1599-611.

2. Hendrix H, Kamlak V, Prisadov G, Welcker K. Pain treatment after thoracic surgery. Zentralbl Chir 2017;142:337-47.

3. Kaushal B, Chauhan S, Saini K, Bhoi D, Bisoi AK, Sangdup $T$, et al. Comparison of the Efficacy of Ultrasound-Guided Serratus Anterior Plane Block, Pectoral Nerves II Block, and Intercostal Nerve Block for the Management of Postoperative Thoracotomy Pain After Pediatric Cardiac Surgery. J Cardiothorac Vasc Anesth 2019;33:418-25.

4. Barr AM, Tutungi E, Almeida AA. Parasternal intercostal block with ropivacaine for pain management after cardiac surgery: a double-blind, randomized, controlled trial. J Cardiothorac Vasc Anesth 2007;21:547-53.

5. Dowling R, Thielmeier K, Ghaly A, Barber D, Boice T, Dine A. Improved pain control after cardiac surgery: results of a randomized, double-blind, clinical trial. J Thorac Cardiovasc Surg 2003;126:1271-8.

6. Shamim F, Ullah H, Khan FA. Postoperative pain assessment using four behavioral scales in Pakistani children undergoing elective surgery. Saudi J Anaesth 2015;9:174-8.

7. Sessler CN, Grap MJ, Ramsay MA. Evaluating and monitoring analgesia and sedation in the intensive care unit. Crit Care 2008;12:S2.

8. McDonald SB, Jacobsohn E, Kopacz DJ, Desphande S, Helman JD, Salinas F, et al. Parasternal block and local anesthetic infiltration with levobupivacaine after cardiac surgery with desflurane: the effect on postoperative pain, pulmonary function, and tracheal extubation times. Anesth Analg 2005;100:25-32.

9. Shelly MP, Park GR. Intercostal nerve blockade for children. Anaesthesia 1987;42:541-4.

10. Matsota P, Livanios S, Marinopoulou E. Intercostal nerve block with Bupivacaine for post-thoracotomy pain relief in children. Eur J Pediatr Surg 2001;11:219-22.

11. Lukošienė L, Kalibatienė L, Barauskas V. Intercostal nerve block in pediatric minimally invasive thoracic surgery. Acta Medica Lituanica 2012;19:150-3.

12. Tokgöz O, Beyaz SG, Tanriverdi B. Effects of parasternal block and local anaesthetic infiltration by levobupivacaine on postoperative pain and pulmonary functions after offpump coronary artery bypass graft surgery. Turkish $\mathrm{J}$ thorac Cardiovasc Surg 2011;19:24-9.

13. Osinowo OA, Zahrani M, Softah A. Effect of intercostal nerve block with $0.5 \%$ bupivacaine on peak expiratory flow rate and arterial oxygen saturation in rib fractures. J Trauma 2004;56:345-7.

14. Luo M, Liu X, Ning L, Sun Y, Cai Y, Shen S. Comparison of ultrasonography-guided bilateral intercostal nerve blocks and conventional patient-controlled intravenous analgesia 
for pain control after the nuss procedure in children: a prospective randomized study. Clin J Pain 2017;33:604-10.

15. Takamori S, Yoshida S, Hayashi A, Matsuo T, Mitsuoka M, Shirouzu K. Intraoperative intercostal nerve blockade for posthoracotomy pain. Ann Thorac Surg 2002;74:338-41.

16. Lukosiene L, Rugyte DC, Macas A, Kalibatiene L, Malcius $\mathrm{D}$, Barauskas V. Postoperative pain management in pediatric patients undergoing minimally invasive repair of pectus excavatum: the role of intercostal block. J Pediatr Surg 2013;48:2425-30.
17. Lukosiene L, Macas A, Trepenaitis D, Kalibatiene L, Malcius D, Barauskas V. Single shot intercostal block for pain management in pediatric patients undergoing the Nuss procedure: a double-blind, randomized, controlled study. J Pediatr Surg 2014;49:1753-7.

18. Chaudhary V, Chauhan S, Choudhury M, Kiran U, Vasdev S, Talwar S. Parasternal intercostal block with ropivacaine for postoperative analgesia in pediatric patients undergoing cardiac surgery: a double-blind, randomized, controlled study. J Cardiothorac Vasc Anesth 2012;26:439-42. 